\title{
NOTES ON TRANSLITERATION
}

For more than four centuries, Jews in Salonica, as in other parts of the Balkans and the Ottoman Empire, spoke and wrote in a language based on fifteenth- and sixteenth-century Iberian dialects (primarily Castilian but also Aragonese, Leonese, Portuguese, etc.). To this Ibero-Romance base, they integrated linguistic elements from Hebrew and Aramaic, the languages of Jewish tradition; Turkish and Greek, the languages of their neighbors in the Ottoman realm; and, later, Italian and French, the languages of European prestige. Historically printed in various styles of the Hebrew alphabet, both letras de rashi (Rashi script, also known as rabbinical type) and meruba (block type), it was handwritten in a particular style of Hebrew cursive, known as soletreo, until World War II, although some documents appeared in Latin letters earlier.

The language and its different varieties have been identified by several names, including Judeo-Spanish, Ladino, Judezmo, Djudyo, and others. While it is now common practice in English-language scholarship in the United States to refer to all varieties of the language- - printed and spoken, calque translations and original compositions-as Ladino, I have opted to call it Judeo-Spanish in an attempt to reproduce the way that my sources identified the language. For a variety of reasons, by the twentieth century, Jewish journalists and communal leaders in Salonica tended to refer to their spoken language as djudeo-espanyol, derived from the nineteenth-century 
French coinage, judéo-espagnol, and subsequently rendered into Greek as ispanoevraika. My sources from Salonica sometimes referred to the spoken language as Judezmo, especially in popular forums, but almost never as Ladino, which was instead used occasionally to describe calque translations from Hebrew and certain literary or liturgical texts. This was not the case in all communities-in the United States, for example, Ladino gained currency as the name for the spoken language during the interwar period-but the term Ladino was seldom used in Salonica to identify the everyday language of the people.

I have adopted a modified version of the Aki Yerushalayim transcription system, which represents Judeo-Spanish phonetics and pronunciation in order to facilitate broad comprehension. When original sources were composed in Latin letters, I have preserved the author's orthography. In reproducing common names, I have utilized standard spellings in English and French (e.g., Covo instead of Kovo). In order to preserve the flavor of the pronunciation of Hebrew among the Jews of Salonica, I have omitted the " $\mathrm{h}$ " in certain words or expressions of Hebrew origin particular to the locality (e.g., Talmud Tora Agadol, rather than Talmud Torah Ha-gadol), but I have adopted standard English spellings for Hebrew words that are common in English (e.g., Torah rather than Tora to refer to the scrolls of the Five Books of Moses). For Hebrew scholarship and biblical references, and for Modern Greek, I use a simplified version of the Library of Congress system that emphasizes phonetics. For Ottoman Turkish terms known in English, I use the English versions (e.g., pasha rather than paşa).

The name of the city that is the subject of this book has been rendered as Salonica, which, along with Salonika, are the standard English spellings. Jews referred to the city as "Saloniko" (from the Italian Salonicco) in the local Judeo-Spanish press and as "Saloniki" in Hebrew until 1937. That year, the Greek state passed a law compelling the city to be referred to by its Greek name, Thessaloniki, and the post office announced that thereafter it would accept only mail addressed to Thessaloniki. Judeo-Spanish sources after 1937 therefore also referred to the city as "Thesaloniki" or "Tesaloniki" (the latter because it was difficult to represent the theta sound of Greek in the Hebrew-lettered Judeo-Spanish of the era). The city is also called "Selânik" in Turkish, "Solun" in Bulgarian, "Salonique" and "Thessalonique" in French, 
and sometimes "Thessalonica" in English, especially in reference to antiquity. Names of other cities in in the region are identified by their standard, current English names (e.g., Istanbul rather than Constantinople and Izmir rather than Smyrna) unless the sources identify them in other ways.

References to all dates have been preserved in the calendar of the sources. At times in Salonica, as many as four calendars were at play for the city's Jews: Hebrew, Islamic, Gregorian (sometimes identified as ala franka, or $\mathrm{Eu}-$ ropean), and Julian (sometimes identified as ala grega, or Greek). Sometimes multiple dates were used, and I have occasionally noted when that is the case. Sometimes it is not possible to determine whether the Gregorian or Julian calendar was being used. While the Ottoman Empire began using the Gregorian calendar for certain purposes in 1917, Greece did not do so until February 16, 1923, which became March I. Certainly after that date, the reader can assume that all dates provided, other than those in the Hebrew calendar, are in accordance with the Gregorian calendar. 


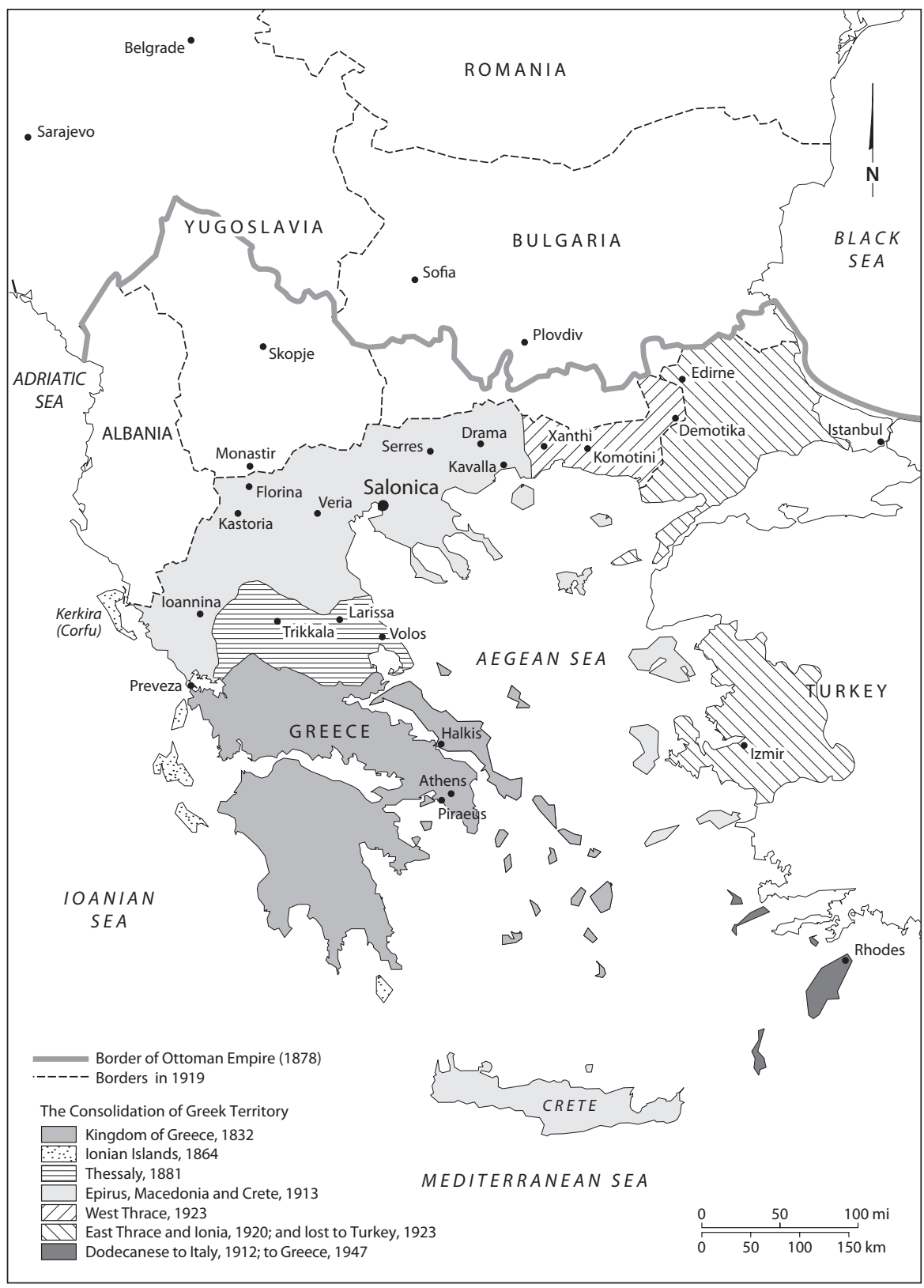

Map I. Salonica in the context of the Ottoman Empire, the Balkans, and Asia Minor during the consolidation of Greek territory, I832-I947. 


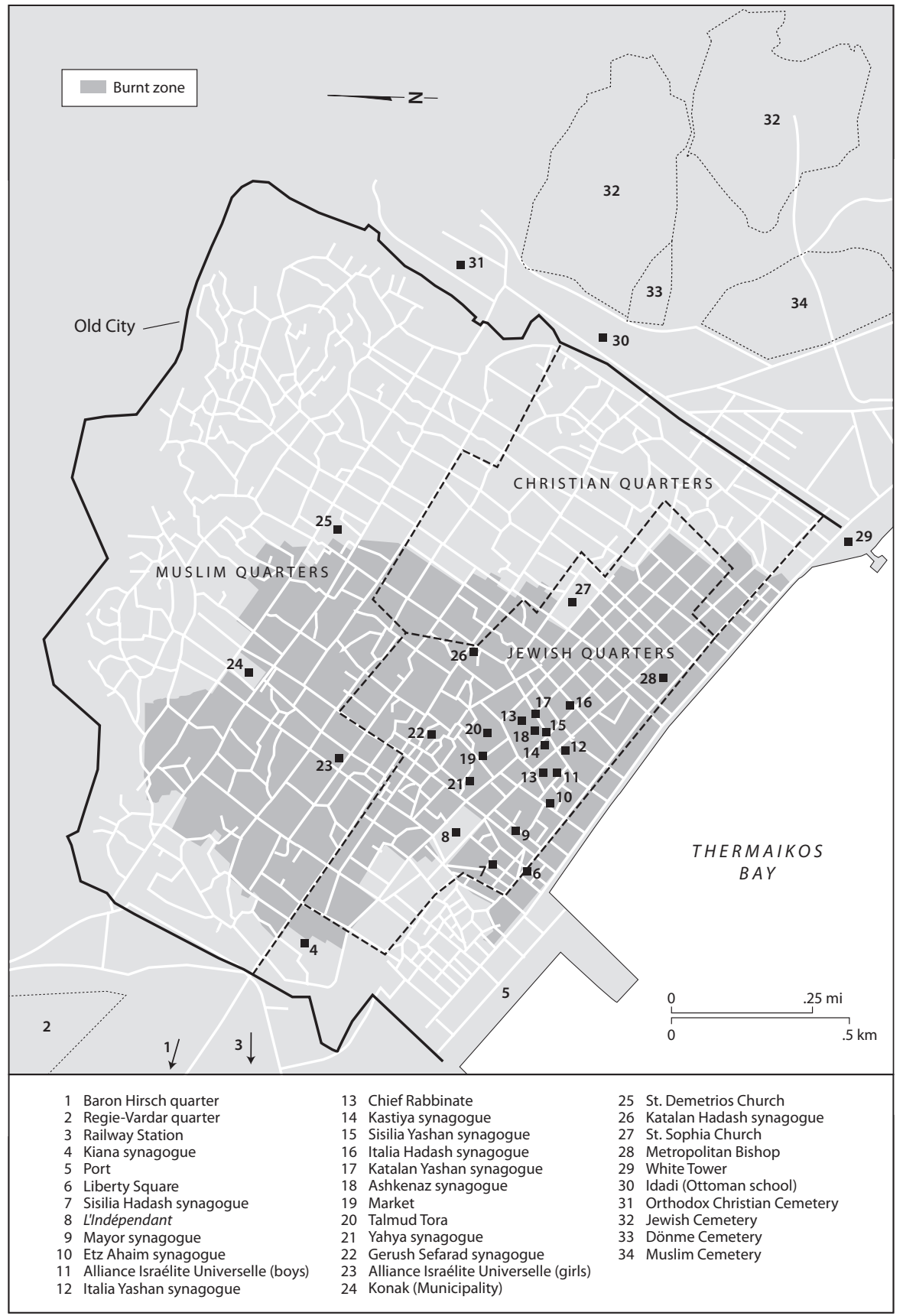

Map 2. Approximate locations of sites of Jewish interest in Salonica before the fire of I917. The boundaries of the Jewish, Christian, and Muslim quarters are not absolute, as members of each community resided elsewhere. 


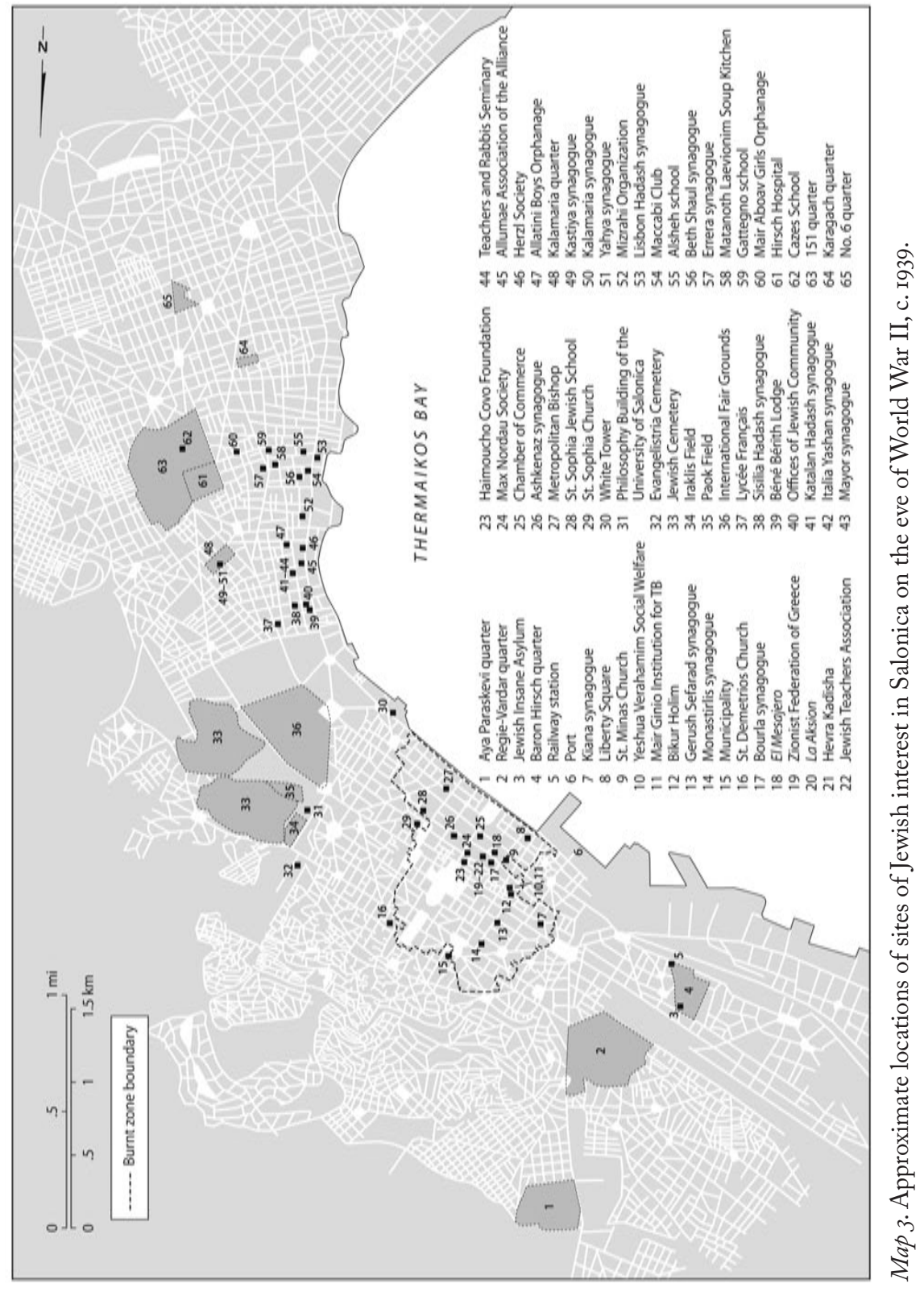


JEWISH SALONICA 
